\title{
METHODOLOGICAL FRAMEWORKS FOR STATE REGULATION OF HEALTH CARE SYSTEM IN THE POST-SOVIET COUNTRIES
}

\author{
Vyacheslav Truba', Viktoriia Borshch ${ }^{2}$, Olha Haran ${ }^{3}$
}

\begin{abstract}
The main purpose of the paper is to analyse the methodological framework for state regulation and public administration of the health care sector in the post-Soviet countries (the case of Ukraine). Methodology. This study combines economic, legal, and managerial analysis of Ukrainian healthcare system. In this study, a complex of the general scientific and special research methods was used to achieve the goal of the study. The method of historical and logical analysis of the literature was used. The functional and structural analysis was used with the purpose to research the state regulation of public relations in health care. Methods of comparative and statistical analysis and their synthesis were used to study the dynamics of development of legal basis in the health care sector. Method of summarization was used to make conclusions and recommendations for optimizing state regulation policy in Ukrainian health care. Scientific works of national and foreign scientists in the sphere of state regulation of health care sphere, national and international legal documents were used as the informational basis for the conducted research. Findings. In the paper, international basis for the formation of the Ukrainian state regulation mechanism is defined. The conceptual basis of state regulation mechanism is analysed. The difference between state regulation and public administration in healthcare is determined. Components of the healthcare market are allocated in order to analyse certain methods of their regulation. Main direct and indirect administrative and economic methods of state regulation in different medical markets are analysed. The framework for medical reformation is determined. Practical implications. The results of this study form the theoretical and methodological basis for practical improvement of the state regulation system of public relations in Ukrainian health care.
\end{abstract}

Key words: health care system, state regulation, economic and legal basis, market relations in healthcare.

JEL Classification: I18, I15

\section{Introduction}

The Constitution of Ukraine considers human being, the right to life and health, right to honour and a good reputation, right to the inviolability of private and family life, right to security as one of the highest values of Ukrainian legal system and a primary assumption for human vital activity (The Constitution of Ukraine). Among other rights, provided by the Constitution, we can highlight the right to medical care as the one, which guarantees human physical existence, and which is essential for maintenance and improvement of Ukrainian nation's health.

State regulation of medical activity in Ukraine is an inseparable part of state policy and public administration in the healthcare field. Nevertheless, the legal framework in the field of health as a key tool of public administration has not been still separated as a legal institute in Ukraine. But the systems analysis of a number of scientific works, regarding the formation and development of the human right to health care, demonstrates the existence of effective attempts to make Ukrainian community responsible for its health.

This research is urgent because of the existence of deliberative issues regarding the state regulation of public relations in the healthcare field not only in the national but also in the international science. Thus, it is necessary to solve some social contradictions. These contradictions in the public administration activity deepen understanding of the objective patterns for its functioning, development, and improvement, and have a crucial impact on the adequate interpretation of the essence of managerial phenomena and processes in the healthcare field.

The goal of this paper is to analyse the methodological framework for state regulation and public administration of the Ukrainian health care sector. To meet this goal, the following tasks have been put before the researches:

\footnotetext{
Corresponding author:

${ }^{1}$ Odesa I.I. Mechnikov National University, Ukraine.

E-mail: truba-v@ukr.net

${ }^{2}$ Odesa I.I. Mechnikov National University, Ukraine.

E-mail: viktoriyaborshch@gmail.com

${ }^{3}$ Odesa I.I. Mechnikov National University, Ukraine.

E-mail: olgast1@bigmir.net
} 
1) to define international frameworks as the basis for state policy formation in health care,

2) to determine the conceptual basis for state regulation and public administration in the healthcare field;

3 ) to analyse the system of state regulation methods in Ukrainian health care;

4) to propose the directions for medical reformation in Ukraine.

The issues related to defining the relationships between state regulation of medical activity and the level of lawyer in the healthcare, managerial and medical staffs' training is still poor researched. Methodological, organizational, and legal frameworks for medical state regulation and developing the legal instruments for transplantation, euthanasia, reproductive medicine and so on require further improvement.

\section{Methodology}

This study combines economic, legal, and managerial analysis of Ukrainian healthcare system. In this study, a complex of general scientific and special research methods was used to achieve the goal of the study. The method of historical and logical analysis of the literature was applied. The functional and structural analysis was used with the purpose to research the state regulation of public relations in health care. Methods of comparative and statistical analysis and their synthesis were used to study the dynamics of development of legal basis in the health care sector. Method of summarization was used to make conclusions and recommendations for optimizing state regulation policy in Ukrainian health care.

Scientific works of national scientists in the sphere of state regulation and public administration of the Ukrainian health care sphere, national and international legal documents were used as the informational basis for the conducted study.

\section{International frameworks for state policy formation in health care}

Formation of Ukrainian state policy in the health care is characterized by the general patterns, which are universal for most countries. The law of Ukraine "Fundamentals of the Legislation of Ukraine on Health Care" dated November 19, 1992 (No 2801-XII, revised on June 10, 2018) (Law of Ukraine Fundamentals...) determines that the state and community guarantee the priority of health care in the country's activity. In the formation of state policy, the principles of international treaties, in which Ukraine participates, have to be used.

European Code of Social Security (Strasburg, 1962) (European Code of Social Security Treaty) and Charter on Social Rights (Havana, 1982) (Charter on Social Rights) are the policy documents, which are the main for the most countries in developing the state policy in the health care field. The main frameworks for the formation of healthcare state policy and strategy were declared at the first International Conference on Health Promotion (Canada, 1986) and are known as the Ottawa Charter for Health Promotion (Charter adopted at an international conference on health promotion). It provides for the implementation of a new managerial technology in the healthcare field, based on the cross-sectoral approach.

At this conference, it was determined that health determinants are biologically and socially resulted and programmed, and the state policy on health promotion must combine diverse but complementary approaches including legislation, fiscal measures, taxation and organizational change and requires the identification of obstacles to the adoption of healthy public policies in non-health sectors, and ways of removing them (Charter adopted at an international conference on health promotion).

The following directions must be realized, in accordance with the Charter for Health Promotion: (1) to build the health policy, based on a cross-sectoral approach; (2) to create supportive environment, based on socio-ecological approach to health; (3) to strengthen community actions in setting priorities, making decisions, planning strategies, and implementing them to achieve better health; (4) to develop personal and social skills through providing information, education for health, and enhancing life skills; (5) to reorient health system for disease prevention and primary medical care (Charter adopted at an international conference on health promotion).

Thus, the main goals, which meet this Charter and are crucial for the development of the healthcare sector worldwide, are the following:

1) to move towards the healthy public policy and to advocate a clear political commitment to health and equity in all sectors;

2) to counteract the pressures towards harmful products, resource depletion, unhealthy living conditions and environments, and bad nutrition; and to focus attention on public health issues such as pollution, occupational hazards, housing and settlements;

3) to respond to the health gap within and between societies and to tackle the inequities in health produced by the rules and practices of these societies;

4) to acknowledge people as the main health resource; to support and enable them through financial and other means, and to accept the community as the essential voice in matters of its health, living conditions, and wellbeing;

5) to reorient health services and their resources towards the promotion of health;

6) to recognize health and its maintenance as a major social investment and challenge (Charter adopted at an international conference on health promotion).

The right to health (Article 12) was defined in General Comment 14 of the Committee on Economic, Social and Cultural Rights - a committee of Independent Experts, responsible for overseeing adherence to the Covenant (General Comment). 
All above-mentioned and other international Charters and Declarations form the next core elements of a human right to health. They are (1) progressive realization using maximum available resources; and (2) non-retrogression, i.e., the state should not allow the existing protection of the right to deteriorate unless considering all the options, assessing the impact and fully using its maximum available resources.

The main features of the right to health are its availability, accessibility, acceptability, and quality.

Thus, worldwide, the human right to health must be met by the national state healthcare programs and policy on national and regional levels by looking at underlying determinants of health as a part of a comprehensive approach to health and human rights (Human rights and health).

\section{The conceptual basis for state regulation of health care}

Legal science defines the "state regulation" concept as the State's exercise of a set of activities (organizational, legal, economic and so on) in the field of social, economic, political, cultural, and other public processes with the purpose to harmonize them, to lay down general rules and norms of social behaviour, and to prevent any adverse effects in the society (Shemchuchenko, 1999).

Public administration and state regulation are two separate types of state activity. Public administration supposes a direct managerial impact on the management objects by means of administrative powers and methods, characterized by the directive guidelines and instructions for their performance.

State regulation supposes only imposing limits and bounds for facilities, under which they could freely operate. State regulation, unlike the public administration, is directed not only to the management object but also to the environment. Therefore, state regulation is wider in power influence, then public administration.

The state regulation in the health care field supposes formation of general norms and rules for the realization of medical activity, i.e. medical care, responsibility for these following rules, the influence of the government and its authorities on the medical entities' activity. It must be based on the adequately formed strategy of the community development, state medical programs, medical standards and gears of their mandatory execution, state control and administration coercion. The government uses not only legal but also organizational, financial, personnel, and others tools.

Thus, the state regulation in the health care field must be based on the national budget, tax, credit, investment, monetary, financial, scientific, technical policies, i.e. the regulation has to be provided through regulations, state budget, state control, tax system, standards, customs tariffs, and prioritization.

Therefore, one of the main tasks of the socially oriented country is a balance between citizens' interests in the qualitative and highly qualified medical care and its providers, which are the medical entities and employees. So, on the one hand, the government must satisfy the expectations and interests of its citizens in their right realization on the medical care, and on the other, satisfy the interests of medical providers. At the same time, it must encourage providers to provide as much as possible qualitative services at low costs.

So, we can emphasize that the state regulation of health care is directed to the creation of favourable organizational and financial conditions for medical entities in market conditions. Thus, such a regulation does not suppose government intervention into organizational and vocational activity, except for cases specified by law.

The main goal of the state regulation in the health care field is strengthening of human health, preventive health care, providing the highly qualified medical care, improving the quality life, and preservation of the gene fund of Ukrainians.

The main tasks of state regulation in health care is (1) to impact on the development of the medical entities in all forms of property; (2) to control the quality level of medical services and medical care for solving social problems, related to health; (3) to introduce legislation ensuring equal conditions for the medical entities; (4) to implement strong demographic policy directed to increasing the fertility level and mortality reduction; (5) to expand access to medical assistance for population; (6) to ensure sanitary and epidemiologic well-being for population; (7) to provide the effective multi-channel financial system and to increase the state financial support in the health care field; (8) to encourage the population to healthy lifestyle; (9) to intensify the development of the medical and pharmaceutical industry, including medical appliance and medical items manufacturing, drug production and so on.

State regulation in healthcare has two main components, presented in Figure 1.

Objects of health state regulation are the specific relationships and phenomena, branches of medical and other types of activities in healthcare, system, territorial, branch, and functional subsystems of the Ukrainian health care sector. We can allocate two types of health state regulation's objects: (a) material and (b) intangible. To the first group, we can include medical entities, their staff, fixed capital, financial resources. To the second one, we can attribute work relations, relations between patients and staff of the medical entities, intellectual capital and so on. But the main object of such a regulation is human health and its status, which we can influence improving it.

The main subjects of health state regulation in Ukraine are the Verkhovna Rada of Ukraine, President of Ukraine, National Security Council, central executive authorities, among which is the Ministry of Health of Ukraine, and also local executive authorities (Hladun, 2007). 


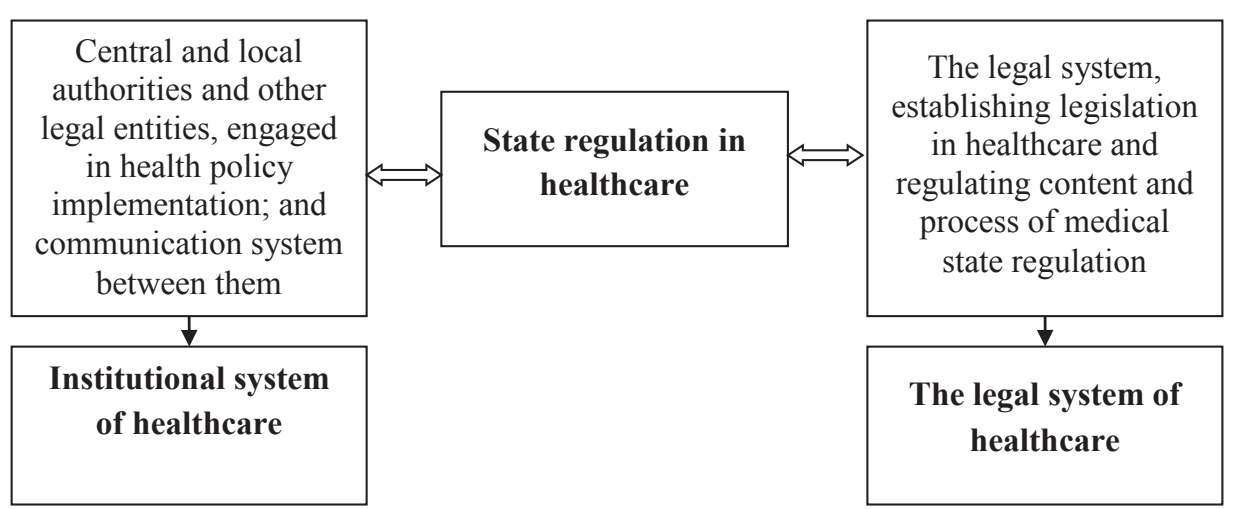

Figure 1. Components of state regulation in the health care field

\section{Methods of state regulation in the healthcare field}

Achieving the goals of state regulation of any socioeconomic field is provided by a number of methods. Methods of state regulation are the ways of state influence on business, market infrastructure, a nonprofit economic sector in order to create conditions for their effective functioning, considering directions of economic and social policy.

We can classify methods of state regulation by two attributes: by forms and means of influence.

According to means of influence, there are (a) administrative methods, based on the state authority, include prohibitory, permitting and coercion measures; (b) economical methods create particular conditions and guide the development of the socio-economic relations to the right way.

According to the forms of influence, there are (a) direct methods impact the market actors' functioning by means of administrative, legal, and economic tools of direct influence; (b) indirect methods impact the market actors' functioning by means of creating the particular economic conditions and environment, enforcing them to move to the certain direction; it is an influence on the economic interests.

Health care sector includes a number of interrelated markets, such as medical services market, the market for medical technologies and equipment, health insurance market, labour market, medical education market, pharmaceutical market, and financial market (Figure 2).

Thus, taking into consideration the general classification of the state regulation methods and structure of the healthcare market, we can identify the following groups:

1) according to means of state regulation, there are:

- tools, used in the context of administrative methods;

- tools, used in the context of economic methods;

2) according to the forms of state regulation, there are:

- direct methods;

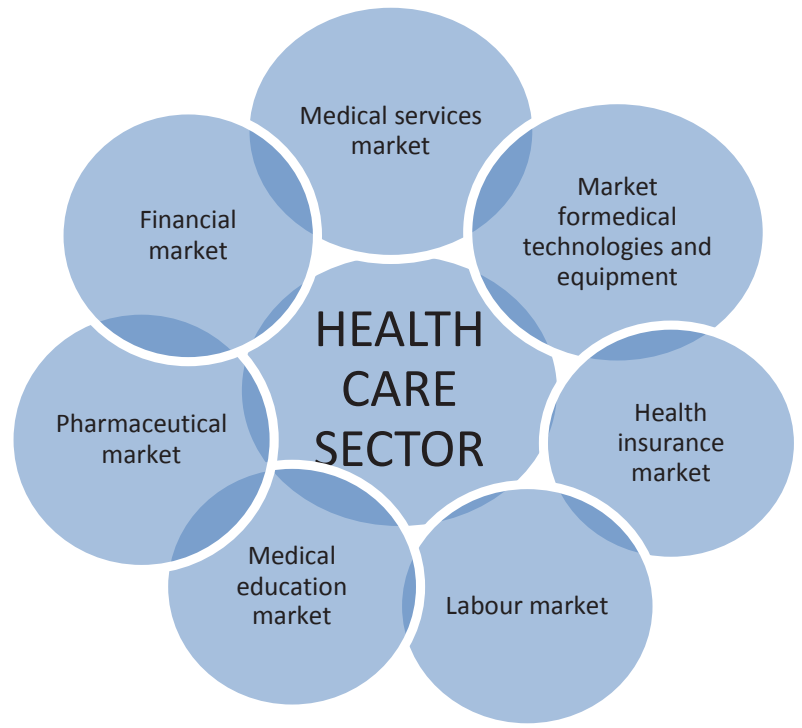

Figure 2. Structure of the healthcare market

- indirect methods;

3) according to the market of the healthcare sector, there are:

- tools, used for regulation of the medical services market;

- tools, used for regulation of medical technologies and equipment market;

- tools, used for regulation of the medical insurance market;

- tools, used for regulation of the labour market and the market for medical education;

- tools, used for regulation of the pharmaceutical market;

4) according to the instruments, used in the healthcare markets, there are:

- tools, used for increasing supply and medical services (goods) quality;

- tools, used for increasing effective demand for medical services and goods (Ivanov, Berezhna, 2014).

In Table 1, we have classified tools of state regulation in the Ukrainian healthcare market. 
Table 1

Consolidated table of state regulation methods in the Ukrainian healthcare field

\begin{tabular}{|c|c|c|c|}
\hline \multicolumn{4}{|c|}{ 1. Medical services market } \\
\hline \multirow{3}{*}{$\begin{array}{l}\text { Tools in the context of } \\
\text { administrative methods (direct) }\end{array}$} & \multicolumn{3}{|c|}{ Tools in the context of economic methods } \\
\hline & \multirow{2}{*}{$\begin{array}{l}\text { Tools in the context of direct } \\
\text { economic methods }\end{array}$} & \multicolumn{2}{|c|}{$\begin{array}{l}\text { Tools in the context of indirect economic methods } \\
\text { focused on encouraging }\end{array}$} \\
\hline & & $\begin{array}{l}\text { supply and medical services } \\
\text { (goods) quality }\end{array}$ & $\begin{array}{l}\text { effective demand for medical services and } \\
\text { goods }\end{array}$ \\
\hline $\begin{array}{l}\text { - Licensing of medical activity; } \\
\text { - Accrediting and registration of } \\
\text { medical entities; } \\
\text { - Standardization of medical } \\
\text { services quality. }\end{array}$ & $\begin{array}{l}\text { - State financial support for the } \\
\text { healthcare sector. }\end{array}$ & $\begin{array}{l}\text { - Exemption from profit } \\
\text { taxes; } \\
\text { - Exemption from land } \\
\text { charges. }\end{array}$ & $\begin{array}{l}\text { - Exemption from VAT for medical services; } \\
\text { - Particular costs, related to healthcare } \\
\text { inclusion to the expenses of income tax payer; } \\
\text { - Medical goods' (services) cost exclusion } \\
\text { from the calculation of the general month } \\
\text { taxable income of income tax payer; } \\
\text { - Medical goods' (services) cost inclusion } \\
\text { to tax credit. }\end{array}$ \\
\hline \multicolumn{4}{|c|}{ 2. Market for medical equipment and technologies } \\
\hline \multirow{3}{*}{$\begin{array}{l}\text { Tools in the context of } \\
\text { administrative methods (direct) }\end{array}$} & & Tools in the context of econon & ic methods \\
\hline & \multirow{2}{*}{$\begin{array}{l}\text { Tools in the context of direct } \\
\text { economic methods }\end{array}$} & \multicolumn{2}{|c|}{$\begin{array}{l}\text { Tools in the context of indirect economic methods } \\
\text { focused on encouraging }\end{array}$} \\
\hline & & $\begin{array}{l}\text { supply and medical services } \\
\text { (goods) quality }\end{array}$ & $\begin{array}{l}\text { effective demand for medical services and } \\
\text { goods }\end{array}$ \\
\hline $\begin{array}{l}\text { - Protection of intellectual } \\
\text { property rights by means of } \\
\text { patenting objects of intellectual } \\
\text { property; } \\
\text { - Registration and certification of } \\
\text { medical equipment. } \\
\end{array}$ & $\begin{array}{l}\text { - Financial support for medical } \\
\text { scientific researches; } \\
\text { - Financial support for } \\
\text { purchasing equipment. }\end{array}$ & - & $\begin{array}{l}\text { - Exemption from an excise tax of sales } \\
\text { transactions of cars for invalids; } \\
\text { - Use of lower VAT rate at a level of 7\% } \\
\text { to operations related to delivery and } \\
\text { import of medical items and/or medical } \\
\text { equipment for clinical researches. }\end{array}$ \\
\hline \multicolumn{4}{|c|}{ 3. Pharmaceutical market } \\
\hline \multirow{3}{*}{$\begin{array}{l}\text { Tools in the context of } \\
\text { administrative methods (direct) }\end{array}$} & \multicolumn{3}{|c|}{ Tools in the context of economic methods } \\
\hline & \multirow{2}{*}{$\begin{array}{l}\text { Tools in the context of direct } \\
\text { economic methods }\end{array}$} & \multicolumn{2}{|c|}{$\begin{array}{l}\text { Tools in the context of indirect economic methods, } \\
\text { focused on encouraging }\end{array}$} \\
\hline & & $\begin{array}{l}\text { supply and medical services } \\
\text { (goods) quality }\end{array}$ & $\begin{array}{c}\text { effective demand for medical services and } \\
\text { goods }\end{array}$ \\
\hline $\begin{array}{l}\text { - Registration and standardization } \\
\text { of medicines' quality and medical } \\
\text { items; } \\
\text { - Licensing of the production, } \\
\text { wholesale and retail trade of } \\
\text { medicines and medical items; } \\
\text { - State price control for medicines } \\
\text { and medical items. }\end{array}$ & $\begin{array}{l}\text { - Financial support for } \\
\text { medicines and medical items } \\
\text { purchasing. }\end{array}$ & $\begin{array}{l}\text { - Exemption from fee } \\
\text { for the certain types of } \\
\text { activity for apothecary, for } \\
\text { delivery of the medicines } \\
\text { and purchasing of the } \\
\text { preferential business license } \\
\text { (trade patent). }\end{array}$ & $\begin{array}{l}\text { - Use of lower VAT rate at a level of } 7 \% \text { to } \\
\text { operations related to delivery and import } \\
\text { of medicines; } \\
\text { - Duty-free for pharmaceutical production; } \\
\text { - Use of lower VAT rate at a level of } 7 \% \text { to } \\
\text { operations related to delivery and import } \\
\text { of medicines for clinical researches. }\end{array}$ \\
\hline \multicolumn{4}{|c|}{ 4. Medical insurance market } \\
\hline \multirow{3}{*}{$\begin{array}{l}\text { Tools in the context of } \\
\text { administrative methods (direct) }\end{array}$} & \multicolumn{3}{|c|}{ Tools in the context of economic methods } \\
\hline & \multirow{2}{*}{$\begin{array}{l}\text { Tools in the context of direct } \\
\text { economic methods }\end{array}$} & \multicolumn{2}{|c|}{$\begin{array}{l}\text { Tools in the context of indirect economic methods } \\
\text { focused on encouraging }\end{array}$} \\
\hline & & $\begin{array}{l}\text { supply and medical services } \\
\text { (goods) quality }\end{array}$ & $\begin{array}{l}\text { effective demand for medical services } \\
\text { and goods }\end{array}$ \\
\hline - Licensing of insurance activity. & $\begin{array}{l}\text { - Functioning of the Fund of } \\
\text { social insurance for labour } \\
\text { accidents and professional } \\
\text { diseases in Ukraine. }\end{array}$ & - & $\begin{array}{l}\text { - Costs for health insurance inclusion to } \\
\text { the total costs of the income tax payer. }\end{array}$ \\
\hline \multicolumn{4}{|c|}{ 5. Labour market and medical education market } \\
\hline \multirow{3}{*}{$\begin{array}{l}\text { Tools in the context of } \\
\text { administrative methods (direct) }\end{array}$} & \multicolumn{3}{|c|}{ Tools in the context of economic methods } \\
\hline & \multirow{2}{*}{$\begin{array}{l}\text { Tools in the context of direct } \\
\text { economic methods }\end{array}$} & \multicolumn{2}{|c|}{$\begin{array}{l}\text { Tools in the context of indirect economic methods } \\
\text { focused on encouraging }\end{array}$} \\
\hline & & $\begin{array}{l}\text { supply and medical services } \\
\text { (goods) quality }\end{array}$ & $\begin{array}{c}\text { effective demand for medical services and } \\
\text { goods }\end{array}$ \\
\hline $\begin{array}{l}\text { - Licensing and accreditation of } \\
\text { educational establishments; } \\
\text { - Standardization of the quality of } \\
\text { educational services. }\end{array}$ & $\begin{array}{l}\text { - Financial support for } \\
\text { training, retraining, further } \\
\text { training and remuneration of } \\
\text { medical staff. }\end{array}$ & - & - \\
\hline
\end{tabular}


Thus, from Table 1 we see that the main tools used in all healthcare markets are administrative direct methods, such as licensing, accreditation, standardization and price control. The direct economic method is the financial support of different medical activities, e.g. medical scientific researches, education and training, purchase of medical equipment, medicines and so on. Indirect economic methods are represented by tax regulation policy.

So, we can argue that the ratio of direct administrative and economic methods in the Ukrainian state regulation system is $40 \%$ both; $15 \%$ is a ratio of indirect economic methods, directed to the effective demand for medical services and goods; and 5\% is for indirect economic methods, directed to supply and medical services (goods) quality in the system of state regulation methods (Figure 3).

Analysis of the state regulation methods allows making a conclusion that state regulation is fragmented, leading to its improvement because the complex state regulation of all related healthcare markets is not provided. It complicates the process of market relations formation and reduces the effectiveness of medical reforms in Ukraine.

\section{State regulation of market mechanisms in the healthcare field}

The position that market relations in the healthcare sector cannot be spontaneous and not regulated, and the scope of market laws must be limited, is generally accepted. The healthcare, indeed, is the specific branch, which could not be fully oriented only on the market relations. The necessity of limitation of market relations in healthcare is due to its specificity. First of all, this is because of the humanitarian focus of medical activity, which is provided for the supremacy of the medical results over financial ones. And in this regard, the scope of market relations is limited. Humanity, fairness, and quality of medical care must be the requirement under any economic relations. Thus, research on the use of direct and indirect administrative and economic methods in the different markets of the healthcare sector presented above is urgent. In this way, the effectiveness of the healthcare sector should be accessed from the position of medical, social, economic, and financial activities. So we see that medical entities mostly act despite the economic calculations, principles, and their profitability. Thus, it is necessary to structure medical services, which can be or cannot be involved in market relations. From the other hand, the market relations in healthcare cannot exist per se, because of the position of the state as a monopolist. For what it's worth, we could not avoid the state regulation.

The following criterion could be defined in order to determine the spheres of state (non-market) medical segments: (1) ratio of expenditures on provision of free medical care with the expenses, which are transferred to the population in case of its absence; and (2) state's economic opportunities and welfare of population.

Therefore, to provide an effective healthcare system, a viable management mechanism in the healthcare field must be developed. It must combine:

- The centralized budget allocation of leading medical and educational medical centres;

- financing of the prevention medicine from the local budgets;

- financing of other types of medical care from the insurance funds;

- transition of some medical services on commercial (paid) base.

The shift of the healthcare sector to a market economy provides for the following changes in the medical business model:

1) To change the organizational and legal status of medical entities, i.e. their transformation to the independent legal entity with wide-ranging powers;

2) To change property forms of many medical entities in order to form the significant commercial sector of healthcare;

3) To change the nature of relations between the medical stakeholders from social and administrative towards economic ones;

4) The shift from the financing of medical entities towards financing medical care. This supposes

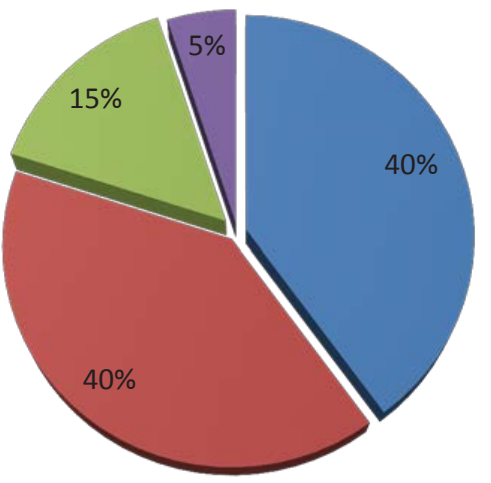

Direct administrative methods

Direct economic methods

- Indirect econonomic methods for effective demand

- Indirect econonomic methods for effective supply

Figure 3. The ratio of methods in the general system of state regulation methods 
identification of standard costing for particular diseases treatment. Thus, the main task of public health is to define expenses for healthcare in accordance with the prevalence rate;

5) To change the financial principle from costs financing towards the purchase of medical services by the payer; 6) To change the flow of funds for healthcare by addition to financing from the taxes the compulsory contribution from compulsory and voluntary health insurance and direct payment for medical care;

7) Decentralization of financing;

8) To increase sources of funding, i.e. a number of sources should be used (insurance payments, direct payments and so on) instead of one source from the state budget.

\section{Conclusions}

In drawing conclusions, it is necessary to emphasize that around the time of Ukrainian independence, the formation of modern medical law, the shift from state monopoly in healthcare towards diversifies healthcare system, based on competitive markets, is a real progress of our country. This enhances the quality of medical care for the population. Modern medical reforms create the basis for autonomization of medical entities and their independent financial, organizational, and business activity; this provides equal rights to all entities of different property forms.

But nevertheless, economic and political crisis and low level of community's prosperity in Ukraine hinder the development of the non-state commercial sector of healthcare, and hence the reformation of the healthcare field. Therefore, the modern medical reformation must take into consideration the gears and methods not only of direct economic and administrative ones but also propose the indirect economic methods of state regulation of health care in order to develop the healthcare market and make it the front-runner of social and economic policies in Ukraine.

\section{References:}

The Constitution of Ukraine (1996). Statements of Verkhovna Rada, 30.

Law of Ukraine Fundamentals of the Legislation of Ukraine on Health Care (November 19, 1992, No 2801-XII, revised on June 10, 2018). Retrieved September 12, 2018 from: http://zakon.rada.gov.ua/laws/show/2801-12

European Code of Social Security Treaty No. 048. Retrieved September 12, 2018 from: https://www.coe.int/en/ web/conventions/full-list/-/conventions/treaty/048

Charter on Social Rights No. 995418 (February 15, 1982). Retrieved September 15, 2018 from: http://zakon.rada.gov.ua/laws/show/9955_418?lang=en

Charter adopted at an international conference on health promotion. The move towards a new public health (November 17-21, 1986 Ottawa, Ontario, Canada). Retrieved September 15, 2018 from: https://www.who.int/ healthpromotion/conferences/previous/ottawa/en/

General Comment No. 14 (2000). The right to the highest attainable standard of health (article 12 of the International Covenant on Economic, Social and Cultural Rights) Retrieved September 14, 2018 from: https://tbinternet.ohchr.org/_ layouts/treatybodyexternal/Download.aspx?symbolno=E\%2fC.12\%2f2000\%2f4\&Lang=en

Human rights and health. Official web-site of WHO. Retrieved September 15, 2018 from: http://www.who.int/ news-room/fact-sheets/detail/human-rights-and-health

Shemchuchenko, Yu. S. (1999). Juridical encyclopedia in 6 volumes, Volume 2, Kyiv.

Hladun, Z. S. (2007). Conceptual basis of state and legal regulation of healthcare. The Proceedings of the $1^{\text {st }}$ Ukrainian scientific and practical conference "Medical law in Ukraine", 19-20.04.2014, Lviv.

Ivanov, Yu. B., Berezhna, Ju. V. (2014). Instrumentation of the health protection sphere state regulation in Ukraine. Economy and region, 4(47), 101-106. 